\title{
Public Debt in Albania and Some Ideas on the Good Management of Public Finances
}

\author{
Dorina Leka ( Klosi)
}

Economist, PhD candidate at European University of Tirana

\section{Doi:10.5901/mjss.2013.v4n10p332}

\section{Abstract}

The material aims to make an analysis of all the numerous public discussions today in Albania regarding the public debt and ways and manners to balance it. Not only in Albania but also in the Euro zone countries like Greece, Spain, Ireland, Cyprus, Portugal, the management and control of public debt is the priority of the economy because of the threat that brings the high public debt on public finances due to macroeconomic instability. Albania's public debt reached in early 2013 to $63.8 \%$ of GDP, while the countries of the region have a lower debt level and higher GDP. There is a law in Albania on the basis of which it is realized such budget management to determine the level which was $60 \%$ of government debt. This level was changed by the Albanian Parliament in December 2012 going to 62\%, a change which was accompanied by heated debates among parliamentary parties and groups of economists. But what should be the level of public debt in order to give breathing to the economy, to promote employment and reduce the unemployment. How will the government be able to come out of the parliamentary elections June 2013 to face the task of improving public finances, efficiency in revenue administration and increasing the sustainability of the fiscal regime, through the implementation of reforms agreed by all political forces and public.

\section{Introduction}

State borrowing, public debt, budget deficit do not represent a simply accounting financial issue. Rather they have a certain content, not just financial, but also economic, social and political one.

Through economic programs and instruments to influence these concepts really and by measuring their impact on welfare of the people, governments are elected and they develop further their political war against opponents.

We can bring to the attention the greater public discussion that accompanied in Albania the government borrowing of 250 million Euro for the construction of a Public Work (street segment Rreshen - Kalimash). Debates about this issue has been ongoing between different political forces, in which are engaged also domestic and international experts.

We can mention also numerous discussions between the main political forces about the flat tax and progressive tax and their application manner in Albania.

There is a direct connection between the budget deficit and effectiveness of public spending. Any further deepening of deficit beyond the permitted norms prevent public investments, economic growth, employment with immediate consequences on economic stability. Therefore, the main objective in terms of management and improvement of public finances is and should be to reduce the budget deficit, borrowing and debt.

The budget as a basic instrument in the hands of the government to implement its policies and goals is the most important point of departure where are applied the fiscal and economic development policies.

Actually there is a law in Albania No. 9936 dated June $26^{\text {th }}, 2008$ "On budget system management" where it is provided the following budget definition: "The state budget is the entirety of the income, expenditure and financing of the central and local government and of special funds adopted by Law from the Parliament of Albania.

Adoption of the budget in Parliament is not a simple process, but there is a struggle between political forces regarding the discussion for the budget adoption.

The budgets of the last two years have been discussed a lot and they are regarded as unrealistic by the opposition in Parliament regarding the planned level of income and determination of rates of economic growth. And in fact since in the early budget years the government has sought to change the budget figures which showed incorrect and responsible planning.

But the biggest discussion ever made about budget changes and still continues to be discussed (and in this discussion are included also the economists circles, representatives of business and academic world) is that about changing the flat of government debt.

And this happened at a time when the budget deficit in Albania had reached to 62\% of GDP.

The Albanian economy in recent years has been developed at a time when the world economy is developing in 
conditions of financial and debt crisis spread to developed countries that gave its effects indirectly also in other countries such as Albania, affecting in reducing the economic growth rates. As Greece and Italy became part of the debt crisis, countries with which Albania has the largest trade exchanges (our country has two thirds of exports with Italy) and the largest number of immigrants caused that the financial crisis gave its effects in Albania a) at the beginning through the fall of remittances and b) return of a large number of immigrants in Albania due to loss of jobs. These were accompanied by a decline of needed liquidity in the economy and declining of domestic consumption.

Discussions of public debt and its role in the stability of public finances and economic growth are realized at its level in relation to GDP, taking as optimal level $60 \%$ of GDP referred to the nominal convergence criteria set by the EU for countries aspiring to become members, while for countries under development it is recommended a debt level below $50 \%$ of GDP.

In Article 58 of Law No. 9936, dated June $26^{\text {th }}, 2008$ "On budget system management" it is required ... "Total public debt, including guarantees, shall not exceed $60 \%$ of GDP limit ..." practically setting a numerical rule on public debt. This fiscal rule is considered easy and does not constitute any legal strong restriction (the law isn't organic and it can be rejected by any annual budget law), but it has established a political order which has played an important role in forcing governments not to exceed the limit of public debt up today, which was decided to pass by adoption in December 2012 of the budget for 2013.

But on the other hand, it is recognized what is important for the public finances is not the numerical level of debt than its durability, ability to finance it and the ability to repay the debt along with interests.

\section{How it is presented the progress of public debt in Albania over the years?}

Tab.1. Public Debt 2005-2011

\begin{tabular}{|c|c|c|c|c|c|c|c|c|}
\hline No. & Denomination & 2005 & 2006 & 2007 & 2008 & 2009 & 2010 & 2011 (plan) \\
\hline 1 & Total Debt & 214,169 & 494,669 & 516,934 & 595,799 & 682,389 & 710,400 & 789,688 \\
\hline A & Domestic Debt & 149,439 & 348,936 & 369,536 & 400,456 & 415,028 & & \\
\hline B & External Debt & 64,730 & 145,733 & 147,398 & 195,343 & 267,361 & & \\
\hline 2 & Total Debt in \% of GDP & 52.34 & 56.07 & 53.48 & 54.77 & 59.68 & $57.85 \%$ & 59.15 \\
\hline 3 & GDP in million ALL & 409,209 & 882,209 & 966,651 & $1,087,867$ & $1,143,373$ & $\mathbf{1 , 2 7 8 , 0 6 8}$ & $1,329,104$ \\
\hline
\end{tabular}

Fig.1
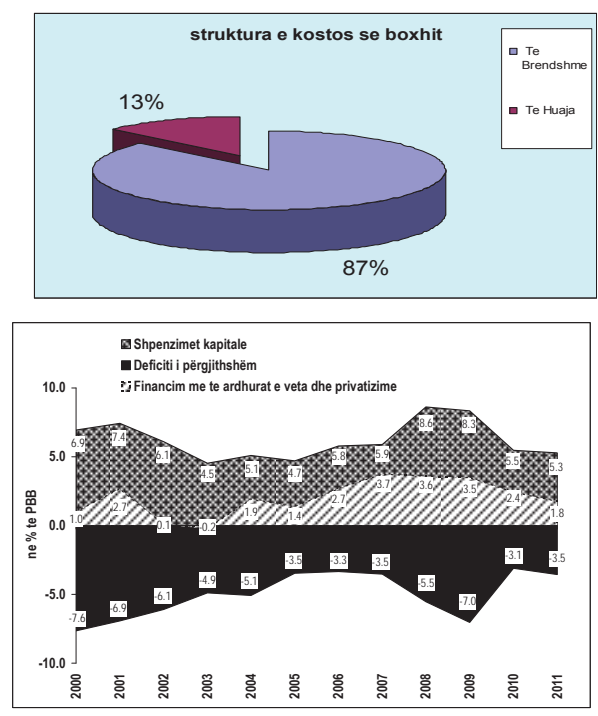


\section{What advise the International Financial Institutions}

World Bank and IMF, the two institutions that over years monitor the progress of economic and fiscal policies in Albania are in unison in terms of public debt. Although they appreciate the fact that the Albanian government and the Central Bank managed to cope till now to affront in an efficient manner the external environment by avoiding a drastic drop in production, or increase and instability of inflation, these two institutions again emphasize the fact that Albania's public debt is high, among the highest in the region, with a high proportion of short-term domestic debt taken mainly (about 70\% of domestic debt) by foreign banks with Albanian deposits.

In an interview with the Albanian daily Panorama, in January 2013, Nadeem Ilahi, the IMF representative states "The further increase of the debt can affect the confidence of those who bought the government debt, it can be deteriorated and come additional risks, as well as restrict the private lending and investments..."

This issue was really verified in early 2013 in treasury bill auctions held by the Ministry of Finance where there was a significant increase in interest rates and a lack of willingness of commercial banks to finance public debt again.

Meanwhile, business is complaining every day about the lack of liquidity due to unpaid debts by the government for the work performed by it mainly in infrastructure, which has put it in serious financial difficulties and in a mistrust position of banks towards business and consequently the contraction of credit granting for business.

In Tirana Chamber of Commerce stated that the debt government has towards the business goes to 200 million Euro, of which 120 million Euro only towards the construction companies that are not paid for the works they have carried out. While the World Bank estimates that this debt is up to 2\% of GDP and represents a new increased risk for the Albanian economy.

Regarding this issue the Governor of the Central Bank at the VOA's show in Albanian language would state: "... it is necessary and a urgent issue the liquidation of debts to businesses. It is the main injection into the economy. No other financial instrument can perform this role at the moment ..."2

The World Bank states that it would be good to deduct the debt level to $40 \%$ as an appropriate level, but also emphasizing payments to businesses.

While the IMF suggested a reduction of debt with a 5-year plan. "... We recommend that the adjustment would be made in the next 5 years, in order to allow a more gradual reduction. At the same time, to perform reliable adjustments, it must be accompanied also by a solid anchor and specific consolidation plans. We have advised the authorities not to cut the projects capital because such activities stimulate the economic activity and create new job positions, especially in difficult times."3

But despite this fact, both institutions that require debt reduction, follow different paths in achieving this goal.

According to the IMF, Albania would have to increase taxes to reduce debt. Tax increases and spending cuts are the safest method for reducing the debt, regardless that according to the experts of the Albanian economy, this model does not stimulate the economic growth.

While debt reduction under the WB should come from tax breaks and business climate that manufacturers mostly. This method would generate income to reduce later State obligations.

In February 2013 WB stated that it would condition the assistance for Albania with the debt reduction and this is the only way to proceed forward with programs of support for Albania. ${ }^{4}$

While the EBRD (European Bank for Reconstruction and Development) in early 2013 appear more optimistic than the other institutions related to economic growth in Albania. According to its forecasts for 2013, the economic growth is expected to amount to $2 \%$ from $1.3 \%$ to this growth forecast by the IMF and WB.

But it strongly emphasis the attention our country should have towards neighbor countries like Greece and Italy. The report of the EBRD for the Albanian economy progress during 2012 noted: "The close connections of Albania in terms of remittances and investments from Greece and Italy, which continued to face economic problems, will continue to intensify ongoing". 5

According to EBRD's President Suma Chakrabarti borrowing is a policy followed by governments in moments the economy has no stimulus, but when borrowing space is limited the attention should be turned on the private sector. "I think this country has decided now is the time to attract private investments to take forces to achieve growth and

\footnotetext{
1 Llahi N, january 27th, 2013 Panorama

2 Fullani A, february 14th, 2013 VOA Broadcast in Albanian Language

3 Llahi N, january 27th, 2013 Panorama

${ }^{4}$ Top Channel, february 22nd, 2013 the news emission

5 EBRD, 2012, Annual Report
} 
development. The public sector can not do still everything, and this is very understandable. Therefore, to further improve the investment climate, we will help in bringing investments in the country as we have done in the past."6

But in a report issued in May for regional economies, EBRD has revised in reduction the previsions for economic growth of Albania from $2 \%$ to $1.5 \%$.

According to EBRD Albanian economy slowed significantly when production fell to $1.6 \%$ and it comes at a time when the government and the Bank of Albania do not have spaces to stimulate the economy, due to increased debt and because of the banking sector is involved by a high percentage of bad loans.

According to EBRD Albania and other Balkan countries should rely more on its own resources and must take a series of internal reforms to prevent the deepening of the crisis.

\section{What really provides the Ministry of Finance..}

And with all the advices and suggestions of international institutions under the government's economic plan, public debt is expected to reach 10 billion dollars by the end of 2016. The government forecast in the 2014-2016 economic plan increases it by almost 1.2 billion dollars, compared with the end of 2012.

8.3 billion dollars was the government debt for 2012. This level of debt is expected to grow to 1.2 billion dollars by the end of 2016. 574 million dollars is expected to increase the debt interest in 2016, of these, 120 million dollars interest on external debt and 454 million dollars for domestic debt. Forecasts for 2013 were to held the debt at $62.6 \%$ of GDP, but only a month after the budget adoption, the government has announced a new figure. In 2013 the debt is expected to increase to $63.8 \%$ of GDP and it is expected to remain at $63 \%$ level up to 2015 , just after this year the debt could be reduced at $62.3 \% .^{7}$

According to experts, there is a factor that can aggravate this prediction and that is situation of the power sector. Forecast of debt stock reduction in 2016 at $62.3 \%$ level could go to $64,4 \%$ if there are implications from the energy sector as there was at the end of 2012 and in early 2013. The largest and most notable privatization of the government in the last eight years was that of electricity distribution proved to be a huge failure because of problems the company CEZ had in the Albanian realty with the old not accumulated debts by not paying the energy in mass by the citizen and a great lack of cooperation between the company and the government. The government was forced to take back the control of the company and the problem has actually passed to international arbitration.

\section{The campaign and economic programs of parties}

2013 coincides with the political elections in Albania. And if we see the economic programs or what the opposition has promised and what has so far made the position there is a little change.

This because ".. in early of this new century, the policy facing and its specific decision-making on matters of socioeconomic development of any country is made conditional on some typical and sustainable phenomena such as globalization, regional integrations, crises or as known otherwise challenges of modernization, possible scenarios of models of capitalism and its modification etc...". ${ }^{8}$

".. Any government that will emerge from the elections should be prepared for the efficiency of public finance and tax administration. There is no place for tax cuts, not only in Albania but in the whole region ..." ${ }^{9}$ stated IMF representatives in their public pronunciation in February 2013.

\section{But what's really happening?}

Larger discussions between the position and opposition are about flat and progressive tax. The government is supporting the flat tax with the arguments that it is paid less, but all pay and because of the simplicity of application of this tax. So the government has an optics with a more liberal economy, small state with limited powers and public responsibility. While the opposition supports the progressive taxation, who earns more, pays more and with criticism on the flat tax that it has not increased employment at all.

\footnotetext{
${ }^{6}$ Chakrabarti S, february 07th, 2013 Panorama

${ }^{7}$ Data provided by dailies february 10th, 2013 Panorama and april 22nd, 2013 MAPO

${ }^{8}$ Civici A, march 16th, march 17th, 2013, MAPO The author is Rector of the European University of Tirana and member of the Supervisory Board of BA.

9 IMF, february 22nd, 2013, Top Chanel, the news emission
} 
It seems that the Albanian government driven also by electoral campaign has chosen the model of WB. In recent months it has removed VAT payment from all machineries entered in our country for investments and it is in the process of a Law draft for VAT exemption from all machineries, equipment and raw materials for the agricultural sector. The government has promised VAT relief in the tourism sector. It has approved the removal of $10 \%$ tax on the minimal wages, measure which would affect 215 thousand employees in the private sector and exemption of youth employed for the first time from all taxes for the first 3 years.

According to experts of the Ministry of Finance, all these measures that will further continue with further reforms in the business environment aim in increasing domestic production and consequently also the exports. Since 2000 the Albanian exports have been increased eightfold bringing about 2 billion Euro in the budget. Their further increase strengthens the Albanian currency (ALL) and the debt repayment becomes easier with a stronger currency.

\section{The effects these measures will have in the state budget}

"In Albania, population and electorate seem to obscure continuously the pure economic and financial logics, but above all the self coherence of economic and social model we apply for. We can not take a little or tax a little and offer many and favor so many. Or the liberal model, tax a little - offer a little or social democrat model - tax a lot and offer a lot. Every promise that affects only one side of the equation, is just a good desire, but very hard to be real as a policy or possibility". ${ }^{10}$

\section{Which is the best solution in the current conditions?}

Economic growth-oriented policies that does not require increase of public spending. Economic growth oriented by domestic product growth, by production and not by consumption, as it is currently oriented, accompanied this with focus on the maximal entering of modern technologies and expansion of human capital, the inclusion of the more active population in contributions and benefits of economic growth.

"The economic growth that exists in an economic and financial terrain dominated by the deficit of payments balance, trade considered deficit, the food market greatly dependent on imports, encouraging the subjective domestic demand, not broad involvement of different social groups and of the territorial integrity in profit contribution from growth, is not assessed as a stable and efficient economic growth."11

There are many things that can be done to improve the business climate such as property registration, relief in tax payment, an element in which Albania is ranked the last in the world. Also the improvement of the power supply or facilities in providing construction permits.

Another important element is the development and growth of exports. Albania has access to the entire European market, which is a market of 14 trillion dollars. We should overview this market and not only the domestic market when it comes to economic growth. In 2004 our exports were about $22 \%$ and increased to $35 \%$, but in a small country like ours they must go to $50-70 \%$.

\section{Recommendations}

- Maximal efficiency in performing public spending.

- A strict implementation of fiscal policies.

- The injection of liquidity into the economy through payment of debts owed to the business, as necessary.

- Encouraging and supporting the banking system to increase business financing.

- Restrict of public borrowing only for investments.

- Promoting the competitiveness of businesses by facilitating the regulatory and fiscal burden.

- Structuring the economy.

${ }^{10}$ Civici A, March 16th, March 17th, 2013, www.mapo.al

${ }^{11}$ Civici A, may 18th, May 19th, 2013 MAPO 


\section{References}

Civici A, march 16th, march 17th, 2013, MAPO The author is Rector of the European University of Tirana and member of the Supervisory Board of BA.

Civici A, March 16th, March 17th, 2013, www.mapo.al

Civici A, May 18th, May 19th, 2013 MAPO

Chakrabarti S, february 07th, 2013 Panorama

EBRD, 2012, Annual Report

IMF, february 22nd, 2013, Top Chanel, the news emission

Data provided by dailies february 10th, 2013 Panorama and april 22nd, 2013 MAPO

Llahi N, january 27th, 2013 Panorama

Fullani A, february 14th, 2013 VOA Broadcast in Albanian Language

Top Channel, february 22nd, 2013 the news emission 